\title{
Demands Made Regarding Federal Prisons During the COVID-19 Pandemic Termite Collective
}

$\mathrm{T}$ he following list of demands was written late March 2020 as the COVID-19 epidemic was hitting so-called Canada. At that point in the epidemic, Correctional Service Canada (CSC) had shut out visitors, volunteers, and lawyers as one of the few measures taken to deal with the approaching crisis. Other prison systems around the world were releasing prisoners in order to make physical distancing possible inside and, therefore, slow the spread of COVID-19 and reduce the risk to prisoners. ${ }^{1}$ Many things seemed possible in that moment and releasing prisoners felt not just like a possibility, but a mainstream demand. The demand, however, was not one that CSC decided to hear.

As of May 2020, there are now two prisoners who died in federal prisons from COVID-19 with hundreds more are infected. Despite claiming to have streamlined parole processes, the numbers of federal prisoners released never really seemed to change from the "old normal". It has never been so clear that prisons are for punishing people.

We are submitting these public demands in the midst of the second wave of the pandemic in the hopes of marking that moment. Despite our disappointment, we continue to hope for the abolition of the prison industrial complex. We will fight with all our might for a future world without prisons and all the systems that make prisons seem necessary.

\section{COVID 19: MEASURES FOR FEDERAL PRISONS}

1. IMMEDIATELY RELEASE ALL VULNERABLE PRISONERS: Anyone over 50 years old, immuno-compromised, pregnant, sick, or who has a pre-existing condition that makes them at high risk of dying from COVID-19.

2. RELEASE ALL PRISONERS, STARTING WITH THOSE IN MINIMUM-SECURITY PRISONS AND HALFWAY HOUSES: According to Correctional Service Canada's own logic, those in minimumsecurity prisons and halfway houses are considered the lowest risk to public safety, so start there. Let those with homes go home, provide safe physical distancing in halfway houses where people choose to remain, widen access 
to Canada Emergency Response Benefit funding to include people getting out of prison and open up vacant housing for those with no homes.

3. TAKE IMMEDIATE SANITARY AND PREVENTATIVE ACTION TO PROTECT THOSE WHO REMAIN IMPRISONED: Provide soap, hand sanitizer with proper alcohol content as recommended by WHO, bleach, cleaning supplies, and self-assessment tools (like thermometers) to every prisoner at no cost. Transfer prisoners in maximum- and medium-security into the empty minimums to allow for proper physical distancing.

4. NO MORE PUNISHMENT. PRIORITIZE CONTINUED ACCESS TO COMMUNITY AND FAMILY FOR THOSE WHO REMAIN IMPRISONED: Free phone calls and video visitation. Allow phone calls and video visitation for volunteers and non-family supports as well. Grant access to cell phones to limit use of communal phones and so that access to the outside continues if medical isolation happens. No lockdowns to inhibit access to community and family supports.

5. MEDICAL SERVICES FOR ALL: Ensure medical services are fully funded, accessible 24/7, and extra health care practitioners are hired. Provide training, PPE, and regular testing. Waive the need for guards to accompany prisoners to the hospital. Do not send prisoners to special military hospitals.

\section{ENDNOTES}

See https://www.reuters.com/article/us-health-coronavirus-myanmar-prisoners/ myanmar-to-free-almost-25000-prisoners-in-largest-amnesty-in-yearsidUSKBN21Z0FR; https:/www.ctvnews.ca/health/coronavirus/indonesia-frees18-000-inmates-from-bursting-jails-over-virus-fears-1.4879152.

\section{CONTACT INFORMATION}

Termite Collective c/o CKUT

3647 University Street,

Montreal, Quebec, H3A 2B3

Email:

demandprisonschange@riseup.net 